http://kitaibelia.unideb.hu/

ISSN 2064-4507 (Online) • ISSN 1219-9672 (Print)

(C) Department of Botany, University of Debrecen, Hungary

23 (2): 117-132.; 2018

DOI: $10.17542 /$ kit.23.117

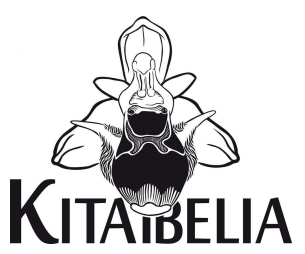

\title{
Magyar botanikusok határozója a dualizmus utolsó éveiből
}

\author{
Szabó Zoltán: Határozókulcs a magyar flóra területén múködő ama \\ botanikusok felismerésére, akik az Album Kleinianumban ábrázoltattak \\ PIFKó Dániel \\ Magyar Természettudományi Múzeum, Növénytár, H-1431 Budapest, Pf. 137; pifko.daniel@nhmus.hu
}

\section{An identification key for Hungarian botanists portrayed in Album Kleinianum (compiled by Zoltán Szabó)}

\begin{abstract}
In the legacy of Sándor Jávorka deposited in the Hungarian Natural History Museum there is a 12-page typescript entitled "An identification key for Hungarian botanists portrayed in Album Kleinianum (Budapest, 25 September 1912)". It provides accurate descriptions of 50 botanists in the form of an identification key, which was compiled by Zoltán Szabó, a well-known botanist at that time. The most important features of each person are presented in a humorous, basically ironic, funny and witty way. The Identification key was prepared for the session no. 178 of the Botanical Section of the Royal Hungarian Natural Science Society, where another botanist, Gyula Klein was congratulated on the $40^{\text {th }}$ anniversary of his teaching profession as well as the $20^{\text {th }}$ anniversary of his membership in the society. Almost all prominent botanists attended the meeting. This paper presents the Identification key, supplied with annotations and photographs.
\end{abstract}

Keywords: archival sources, Botanical Section of the Royal Hungarian Natural Science Society, Gyula Klein, history of botany, humour

Összefoglalás - Jávorka Sándornak a Magyar Természettudományi Múzeumban őrzött hagyatékából került elő egy 12 oldalas gépelt kézirat, amelynek címe „Határozókulcs a magyar flóra területén működő ama botanikusok felismerésére, akik az Album Kleinianumban ábrázoltattak. Budapest 1912. szeptember hó 25.-én". A munka ötven botanikus frappáns leírását tartalmazza határozókulcsba szerkesztve. Szövege humoros, a személyek legjellemzőbb tulajdonságait gyakran élcelődő, ironikus hangnemben mutatja be. Szerzője Szabó Zoltán, korának elismert botanikusa volt. A kézirat a Királyi Magyar Természettudományi Társulat Növénytani Szakosztályának 178. ülésén tartott ünnepségre készült, amelynek egyetlen napirendi pontja Klein Gyula üdvözlése volt, tanári működésének 40-edik, szakosztályi tagságának pedig 20-adik évfordulója alkalmából. Az ünnepségen szinte minden jelentős hazai botanikus részt vett, A cikk végén közöljük Szabó Zoltán Határozójának szövegét, magyarázó jegyzetekkel és fotókkal kiegészítve.

Kulcsszavak: botanikatörténet, forrásközlés, humor, Királyi Magyar Természettudományi Társulat Növénytani Szakosztálya, Klein Gyula 


\section{Bevezetés}

A dualizmus utolsó békeéveiből maradt fenn egy kézirat, mely röviden, tömören és szellemesen, határozókulcsba szerkesztve mutatja be a korszak szinte teljes hazai botanikus közösségét. A kéziratnak köszönhetően képet kaphatunk a legjellemzőbb külső és belső tulajdonságaikról, megelevenednek azok a kutatók, akik vezető pozícióban dolgoztak, de olyan fiatalok is szerepelnek benne, akiknek tudományos munkája később, a két világháború között teljesedett ki.

A Határozó fontos dokumentuma a magyar botanikatörténetnek, de emellett az időszak hangulatát, humorát is jól visszaadja a kézirat, így a művelődés-, kultúra- és mentalitástörténettel fogalakozó kutatók számára is hasznos és szórakoztató olvasmány lehet, ezért jelen cikk végén a teljes szövegét - magyarázó jegyzetekkel együtt - közöljük.

A Határozóban szereplő botanikusok életútjáról pontosabb képet kaphatunk PIFKó (2018) tanulmányából, amely a korszak felsőoktatási intézményeinek botanikai életét mutatja be.

\section{Anyag és módszer}

A Határozó szövegét a Jávorka-hagyatékban megtalált kézirat alapján közöljük, csak a hoszszú/rövid magánhangzók írásán változtattunk a mai helyesírásnak megfelelően. A kéziratot jegyzetekkel láttuk el, hogy segítsük megérteni az abban szereplő utalásokat. A személyek életrajzából csak a Határozó szempontjából fontos adatokat használtuk fel, az egyes személyek neve mellett azt az állást tüntettük fel, amelyet a kézirat születésekor, 1912-ben betöltöttek.

Munkánk során felhasználtuk a Magyarország tiszti cím- és névtára, valamint a Budapesti Czim- és Lakjegyzék évente megjelenő kiadványait is.

A határozókulcsot portrékkal, és a tárgyalt „species”-ek bemutatásával egészítettük ki. A botanikusok fotói jelentős részben a Magyar Természettudományi Múzeum könyvtárának gyűjteményéből származnak. Három gyógyszerészről (Augusztin Béla, Deér Endre, Weber Dezső) készült fotót a Semmelweis Orvostörténeti Múzeumtól kaptuk. Néhány fotó megjelent nekrológokból vagy egyéb kiadványokból származik. Emellett 5 személyről sajnos nem találtunk fotót.

\section{Eredmények}

Jávorka Sándor hagyatékában, melyet a Magyar Természettudományi Múzeum tudománytörténeti gyüjteménye őriz, található egy 12 oldalas géppel írott kézirat, melynek címe Határozókulcs a magyar flóra területén müködő ama botanikusok felismerésére, akik az Album Kleinianumban ábrázoltattak. Budapest 1912. szeptember hó 25.-én. A munka ötven botanikus, vagy valaha a botanikával kapcsolatban álló személy leírását tartalmazza határozókulcsba szerkesztve.

A Határozó Klein Gyula akadémikus, egyetemi tanár és Növénytani Szakosztály-elnök köszöntő ünnepségére készült, melyet 1912. szeptember 25-én tartottak a Növénytani Szakosztály 178. ülésén, melynek egyetlen tárgya Klein Gyula üdvözlése volt tanári működésének 40edik, szakosztályi tagságának pedig 20-adik évfordulója alkalmából.

Az ülésen Mágocsy-Dietz Sándor, a szakosztály alelnöke köszöntötte Klein Gyulát, majd beszéde végén egy albumot adott át neki: „Irántad érzett mély érzésünknek látható kifejezést 
is óhajtunk adni ebben az albumban, a melyben tisztelöid arczképét találod." (ANONYMUS 1912).

Ehhez az albumhoz „mellékletként” készült el a Határozó, melyben az eseményen megjelent személyek szerepelnek. Sajnos az album hollétéről nem tudunk, így azt sem tudjuk biztosan, hogy az albummal együtt nyújtották-e át a Határozót. A gépelt másolaton lévő pontos dátum, illetve a szövegben található függelék arra utal, hogy a munka kicsivel az ünnepség előtt, vagy inkább azzal egy időben készült el.

A Határozó szerzőjeként korábban több bibliográfiában is Ernyey József (1869-1945), a Magyar Természettudományi Múzeum első igazgatója szerepel. Kozocsa Sándor Magyar könyvészeté-ben Ernyey Józsefet nevezi meg a mű szerzőjeként, megadva a Jávorka-féle kézirattal azonos címet, kiadót ugyan nem tüntetett fel, de szerinte a Határozó egy 12 oldalas kőnyomat, amely Budapesten jelent meg 1912-ben (KozocsA 1939). V. Molnár László életrajzi munkájában szintén Ernyey szerzőségével szerepel a mű (V. MolNÁR 2014). A Jávorka-hagyatékban fennmaradt kézirat tehát egy nyomtatásban is elkészült munka másolata lehetett. Sajnos az eredeti nyomtatott változatot nem sikerült megtalálni, így azt sem tudjuk, mi indokolta, hogy a Határozó Ernyey József szerzőségével szerepel a bibliográfiákban. Ernyey egyébként foglalkozott botanikatörténettel, illetve maga is látogatta a Növénytani Szakosztály üléseit, ahol előadásokat is tartott (LENGYEL 1927), arról viszont nincs információnk, hogy az ünnepi ülésen részt vett volna.

Ernyey szerzőségének ellentmond a Magyar Királyi Természettudományi Társulat Növénytani Szakosztályának iratanyagáról fennmaradt lista, melyet a Magyar Természettudományi Múzeum tudománytörténeti gyűjteményében őriznek. A fennmaradt dokumentumban az ünnepséggel kapcsolatos iratok listája is szerepel, mely a következő tételekből állt: „1. Szalóky Róbert beszéde, 2. körlevél, 3. bankett résztvevői, 4. Hauser album számla, 5. Szabóféle határozókulcs, 6.8 drb üdvözlő távirat, 7. bankett menü, 8.12 drb. Üdvözlő levél, 9. Klein Gyula válasza Szalóky beszédére, 10. A Múegyetem ünnepi vacsorája, 11. A szakosztály jegyzőkönyve, 12 Újságcikkek, 13. Moesz Gusztáv kimutatása". A felsorolásban maga az Album Kleinianum Hauser album néven szerepel, ami feltételezésünk szerint azért van így, mert Hauser Samu és Hauser Adolf fényképészek, Népszinház utca 17. szám alatt működő üzletében készült (SZAKÁcs 1997). A listában, amelyet Moesz Gusztáv állított össze az iratokról „Szabó-féle határozókulcs” néven nevezték meg az ünnepségre elkészült Határozót.

A Jávorka-hagyatékban található kézirat hátlapján Jávorka Sándor halvány ceruzás kézírása látható: „Szabó Zoltán botanikus határozója”. Mivel Jávorka jelen volt az eseményen, feltehetőleg tisztában volt azzal is, hogy ki volt a munka szerzője. A bibliográfiákban szereplő adatokkal szemben, a Határozó készítője tehát nem Ernyey József volt, hanem Szabó Zoltán (1882-1944), a Budapesti Egyetem és az Állatorvosi Főiskola magántanára, aki már fiatalon is elismert botanikusnak, taxonómusnak számított, és aki maga is részt vett az ünnepségen.

\section{Megvitatás}

Klein Gyula szakosztályi ünneplése, melynek alkalmából a Határozó készült, igen jeles esemény volt, ennek köszönhető, hogy szinte az összes fontos, növénytannal foglalkozó intézmény vagy tanszék vezetője jelen volt a szakosztály ünnepi ülésén. A távollévőktől beérkezett üdvözlő leveleket és táviratokat Moesz Gusztáv olvasta fel (ANONYMus 1912).

A tudományegyetemek növénytani tanszékeinek mind a két tanára: Mágocsy-Dietz Sándor (Budapest) és Richter Aladár (Kolozsvár) részt vett az eseményen. A Kertészeti Tanintézet vezetője, Angyal Dezső és az iskola Növénytani Tanszékének tanára, Schilberszky Károly szintén jelen voltak, akárcsak a Bányászati és Erdészeti Főiskola Növénytani Tanszékének vezetője, Kövessi Ferenc. A Nemzeti Múzeum Növénytani Osztályának mind a hat 
botanikusa részt vett az ünnepségen (Filarszky Nándor, Kümmerle Jenő Béla, Szepesfalvy János, Jávorka Sándor, Timkó György, Moesz Gusztáv), de Istvánffi Gyula, az Ampelológai Intézet vezetője sem maradt távol. A gyógyszerész szakmát Deér Endre és Wéber Dezső képviselte, illetve a Budapesti Egyetem Növénytanszékén dolgozó Augusztin Béla. A „legnagyobb hiányzó" Degen Árpád volt, aki a budapesti Vetőmagvizsgáló Állomást vezette, de az intézményt munkatársa, Lengyel Géza képviselte.

Többen eljöttek Klein Gyula korábbi műegyetemi tanársegédei közül is. Részt vett az eseményen Lendl Adolf és ifjabb Entz Géza, akik ekkoriban már inkább zoológiával foglalkoztak, de jelen volt Pályi Sándor is, aki ebben az időben aktív tanár és népművelő volt. Egyetemi tanulmányai után Haerter Ádám is dolgozott a Műegyetemen, de ekkor már a ceglédi gimnáziumban tanított (SZŐNYI 1940). Páter Béla, a kolozsvári gazdasági tanintézet igazgatója szintén a Múegyetem tanársegédeként kezdte a pályáját, akárcsak Hollendonner Ferenc. Jelen volt a Műegyetem akkori adjunktusa, Tuzson János is. Emellett szintén részt vettek az ülésen a Növénytani Szakosztály legaktívabb tagjai.

Azt, hogy a dualizmus korának szinte minden jelentős botanikusa megjelent az eseményen nem volt véletlen. Az ünnepelt Klein Gyula (1844-1915) tevékenysége átívelt az egész korszakon. Ő volt a növénytan első tanára a dualizmus első éveiben alapított Műegyetemen, és az 1891-ben alapított Növénytani Szakosztály első alelnökének is őt választották meg, halála már a dualizmus végét jelentő első világháború alatt következett be. A Határozó felfogható tehát, mint egy utolsó vidám „csoportkép” a boldog békeidőkből, a két év múlva bekövetkező világégés előtt, mely a korszakot szinte teljes egészében átívelő tanári pálya megünneplésén készült.

Az első világháború után a Kárpát-medencében dolgozó botanikusok élete jelentősen megváltozott. Bár a háború, szemben a második világháborúval, csak kevés botanikus-életet követelt (Fucskó Mihály), a trianoni békediktátum után többen Magyarország elszakított területein dolgoztak tovább (Nyárády E. Gyula, Margittai Antal, Péterfi Márton, Páter Béla), ami akadálya volt annak, hogy bekapcsolódjanak a Növénytani Szakosztály munkájába. Az első világháború utolsó zavaros éveiben, és az azt követő időszakban a politikai ellentétek is felszínre kerültek. Az ünnepségen részt vevő botanikusok jelentős részének szakmai tevékenysége ebben a politikailag túlfütött időszakban teljesedett ki, majd sokuk élete a második világháború utolsó tragikus éveiben fejeződött be: Polgár Sándor, Gombocz Endre, MágócsyDietz Sándor, Szabó Zoltán, Kövessy Ferenc, Timkó György.

\section{Köszönetnyilvánítás}

Szeretném megköszönni Lőkös Lászlónak a cikk készítése során nyújtott segítséget, és Papp Gábornak, a Növénytár könyvtárosának az irodalmazás során nyújtott áldozatos munkáját. Nagy Enikőnek a Magyar Természettudományi Múzeum könyvtárosának és Blahák Eszternek a Semmelweis Orvostörténeti Múzeum munkatársának, hogy segítettek kikeresni a cikkben szereplő képeket. Szintén a képek keresésében voltak segítségemre az Országos Pedagógiai Könyvtár és Múzeum munkatársai Bogdán Melinda és Borostyániné Rákóczi Mária. Borhidi Attilának és Balogh Lajosnak a kézirathoz füzött tanácsait köszönöm.

\section{Irodalom}

ANDRASOVSZKY J. (1914): Adatok Galatia és Lycaonia flórájához. (Additamenta ad floram Galaticam et Lycaonicam.) - Fritz Ármin Könyvnyomdája, Budapest.

ANGHI Cs. (1964): Lendl Adolf emlékezete. - Állattani Közlemények 51 (1-4): 3-5.

Anonymus (1907): Társulati ügyek. - Természettudományi Közlöny 39 (452): 272-278. 
ANonymus (1908): A Kir. Magy. Természettud. Társ. növénytani szakosztályának 1908 márczius hó 11én tartott ülése. - Magyar Botanikai Lapok 7 (4-8): 268.

Anonymus (1909): Az 1909 junius 9-én tartott ülés. (Sitzung am 9 Juni 1909.). - Magyar Botanikai Lapok 8 (5-9): 265.

ANonymus (1910a): Szakosztályi ügyek. - Botanikai Közlemények 9 (1): 55-66.

Anonymus (1910b): Hazai botanikai dolgozatok ismertetése. (Referate über ungarische botan. Arbeiten.) - Magyar Botanikai Lapok 9 (10-12): 379-402.

Anonymus (1911): Szakosztályi ügyek. - Botanikai Közlemények 10 (1-2): 48-58.

ANonymus (1912): Szakosztályi ügyek. - Botanikai Közlemények 11 (3-4): 162-166.

Anonymus (1940): Dr. Tuzson János. - Index Horti Botanici Universitatis Budapestinensis 4: 5-11.

BALOGH L. (2002): Gáyer Gyula (1883-1932). - In: KöвöLKUTI K. (szerk.), Szombathelyi tudós tanárok II. Berzsenyi Dániel Megyei Könyvtár, Szombathely, pp. 63-101.

BARTHA D. (2009): Kövessi Ferenc (1875-1895) élete és munkássága. - Nyugat-magyarországi Egyetem, Erdőmérnöki Kar, Sopron.

BARTóк K. (szerk.) (2016): Nyárády Erazmus Gyula emlékezete. - Kiterion Kiadó, Kolozsvár.

BeKe M. (1929): Pályi Sándor meghalt. - Az Est 20 (238): 8.

BEzDEK J. (1912): A japán oktatásról. - Tanáregyleti Közlöny 45: 31-46.

BEZDEK J. (1913): A piramisoktól a felhőkarcolókhoz. - Váci Múzeum Egylet, Vácz.

Bogsch S. (1937): Kubacska András Dr. - In: Koch I.: A Budapesti Evangélikus Gimnázium értesítője az 1936/37. iskolai évről. Budapest, pp. 14-19.

DEGEN Á. (1932): Megemlékezés Istvánffi Gyuláról. - Botanikai Közlemények 29: 12-22.

Doвy G. (1910): Cukor-, papiros- és szeszgyártás tengeriből. - A Magyar Mérnök- és Építész-Egylet Közlönye 44 (11): 245-247.

Doвy G. (1911): Az oxidázokról. - Természettudományi közlöny 43 (523): 156.

Doвy G. (1912): A tengeri (Zea mays) női virágzatának oxydaséi. - Mathematikai és természettudományi értesítő 30 (2): 324-339.

Domán I. (1986): Emlékezés Haerter Ádámra. - Békés Megyei Népújság 41 (287): 7.

ENTZ G. (1941): In memóriam Aladári Scherffel. (Lebenslauf von Prof. A. Scherffel.) - A Magyar Biologiai Kutatóintézet Munkái 13: 1-10.

FARKAS Z. \& LÁZÁR L. (szerk.) (2010): Páter Béla emlékezete. - Erdélyi Múzeum-Egyesület, Kolozsvár.

FILARSZKY N. (1911): Növénymorphologia. - Franklin-Társulat, Budapest.

FuCSKó M. (1912): A burgonya hipertrofiás szövetei. - Botanikai Közlemények 11 (1): 14-29.

GYőRFFY I. (1924): Péterfi Márton. 1875. II. 1. - 1922. I. 30. - Botanikai Közlemények 20 (4-6): 117-128.

GYúRó F. (1978): Angyal Dezső élete és munkássága. - Agrártudományi Közlemények 37: 489-499.

Hollendonner F. (1912): A Biota orientalis Endl. és Thuja occidentalis L. fájának hisztologiai megkülönböztetése. - Botanikai közlemények 11 (2): 45-57.

HoNTI J. (2014): A Széchenyi sétány egykor. - Balatonfüredi Napló 14 (1): 5.

Husz B. (1938): Dr. Schilberszky Károly emlékezete (1863-1935). (Karl F. Schilberszky.) - Botanikai Közlemények 35 (1-2): 1-14.

Jávorka S. (1941): Dalmady Zoltán Dr. - In: BARTHA I. \& FöRSTER R. (szerk.): A Kis Akadémia negyvenkét esztendeje az ezredik előadásig 1899-1941. Kis Akadémia, Budapest, pp. 282-284.

JávorKA S. (1947): Gombocz Endre emlékezte. - Botanikai Közlemények 44: 1-8.

KÁRPÁTI Z. (1962): Wagner János emlékezete. (Erinnerung an J. Wagner.) - Botanikai Közlemények 49 $(1-4):$ 5-18.

Kozocsa S. (1939): Magyar könyvészet: 1911-1920, I. kötet A-K. - Kir. M. Egyetemi Nyomda, Budapest.

LENGYEL G. (1927): Visszapillantás a Szakosztály háromszáz ülésére. - Botanikai Közlemények 24 (3-4): 82-91.

Moesz G. (1907): Adatok az Aldrovanda vesiculosa L. ismeretéhez. - Annales Musei Nationali Hungarici 5: 323-399.

MoEsz G. (1936): Gróf Ambrózy-Migazzi István dr. emlékezete. (Erinnerung an den Grafen Dr. Stephan Ambrózy-Migazzi.) - Botanikai Közlemények 33 (1-6): 78-83.

Moesz G. (1941): Hollós László emlékezete 1859-1940. (Erinnerung an L. Hollós.) - Botanikai Közlemények 38 (3-4): 101-118.

MoEsz G. (1943): Filarszky Nándor emlékezete. (Erinnerung am N. Filarszky.) - Botanikai Közlemények 40 (3-4): 147-169. 
NYÁRÁDY E. Gy. (1941): Kolozsvár es környékének flórája. - Erdélyi Nemzeti Múzeum Növénytára, Kolozsvár.

PAÁL Á. (1911): A légritkítás hatása a geotropikus ingerfolyamatra. - Botanikai Közlemények 10 (3-4): 59-88.

PIFKó D. (2018): Botanikai élet a dualizmus kori Magyarországon (1867-1918) I. A felsőfokú oktatás fejlődése és annak hatása a hazai botanikára. (An overview on Hungarian botany in the dualistic era (1867-1918) I. Development of the higher education and its effect on the Hungarian botany.) Botanikai Közlemények 105 (2): 179-222.

RichTER A. (1904, 1905): Egy magyar természetbúvár úti naplójából 1-2 kötet. - Stein, Kolozsvár.

SzABó L. Gy. (2015): A magyar gyógynövénykutatás kiemelkedő alakjai. Visszatekintés a Gyógynövény Kutató Intézet centenáriuma alkalmából. I. rész. - Gyógyszerészet 59: 24-33.

SzABó Z. (1911): A Knautia génusz monographiája. (Monographia gen. "Knautia".) - Mathematikai és Természettudományi Közlemények 31 (1): 1-436.

SzAKÁcs M. (1997): Fényképészek és fényképészmütermek Magyarországon (1840-1945). - Magyar Nemzeti Múzeum, Budapest.

SZŐNYI S. (1940): Haerter Ádám - In: SzELECZKY M. (szerk.), A ceglédi M. Kir. Állami Kossuth-Gimnázium évkönyve az 1939-40. Ceglédi Kossuth Gimnázium, Cegléd, pp. 11-12.

SzTANKoviTs R. (1912): A hazai Carpinusok levelének és termésének histologiája. (Anatomie der Blätter u. Früchte der ung. Carpinus-Arten.) - Botanikai Közlemények 11 (1): 1-13.

Tомек J. (1919): A paprika élénk vörös színének megtartása. - Természettudományi Közlöny 51 (713-714): 61.

Tuzson J. (1911): Rendszeres növénytan I. Általános rész és a virágtalan növények. - Hornyánszky Viktor Cs. és Kir. Udvari Könyvnyomdája, Budapest.

Tuzson J. (1913): Utazásom az orosz pusztákon. - Természettudományi Közlöny 45 (586): 689-712.

Tuzson J. (1926): Rendszeres növénytan II. kötet. Virágos növények. - Szerző és Hornyánszky Viktor R.-T., Budapest.

V. MOLNÁR L. (2014): Ernyey József életmüve. - MATI, Piliscsaba.

WEBER D. (1908): Adatok néhány növénycsalád termésének és magjának anatomiájához. - Növénytani Közlemények 7 (5): 228-233.

ZвоRAY B. (1985): Dr. Weber Dezső (1883-1952). - Gyógyszerészet 29: 227-228.

Beérkezett / received: 2018. 09.18. • Elfogadva / accepted: 2018. 10. 25. 


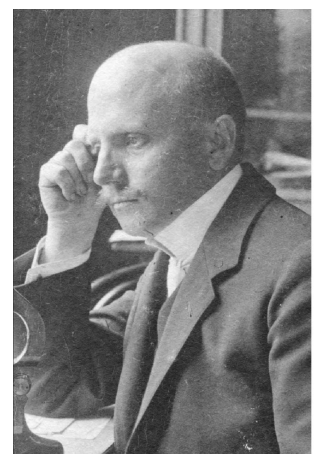

Szurák János

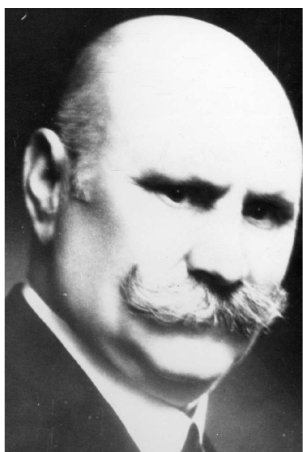

Kubacska András

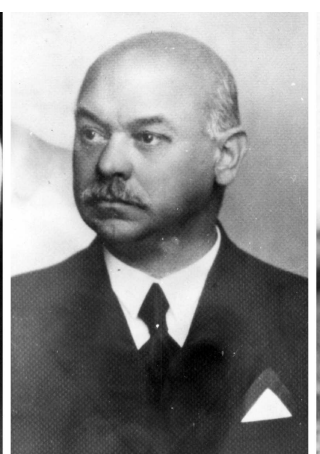

Gombocz Endre

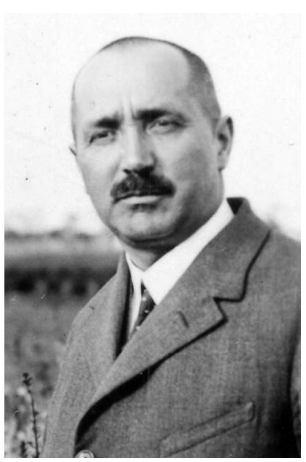

Gáyer Gyula

Szabó Zoltán: Határozókulcs a magyar flóra területén múködő ama botanikusok felismerésére, akik az „Album Kleinianumban”-ban ábrázoltattak

1a Az alsó állkapocs mindig, vagy legalább vasárnap csupasz, sima /: Imberbes ${ }^{1}$ :/ 2

1b Az alsó állkapocs szőrös vagy bozontos /: Barbati ${ }^{2}$ :/ .................................................................. 37

2a A fejtető teljesen, vagy hovatovább sima, fénylő, néha helyenkint szőrös, de csakhamar lekopaszodó

2b A fejtető szőrös vagy sörényes …................................................................................................. 7

3a A fejtető teljesen kopasz, fényes, ragyogó ................................................................................... 4

3b A fejtető helyenkint szőrösödő vagy rákefélt szőrű ............................................................. 5

4a Termete alacsony, oldalszakálla nincs, bajusza rövid, szőke, lekonyuló, vasárnap elálló. A legrosszabb viccre is hangosan kacag. Izgatásra nekivörösödik és heves gesztusok között ordít. Polygam.

Szurák János ${ }^{3}$

4b Termete magas, kis oldalszakálla van, bajusza hosszú, barna, „es ist erreicht”4. Illendően nevet, sohasem ordít csak beszél, ezt is nagy ritkán, de akkor nem lehet kivárni a végit. Monogam $^{5}$.

Kubacska András ${ }^{6}$

5a A fejtetőt itt-ott néhány hajszál fedi, a mely simára lekefélve végig fekszik a fejtetőn, de így sem sikerül elfednie a tar koponyát, a melyről két oldalt mereven elálló görbe függelékek, u.n. fülek merednek szét. Hetenkint felfedez egy-egy hajdani korszakalkotó botanikust. A botanikusok történésznek, a történészek botanikusnak tartják

Gombocz Endre ${ }^{7}$

5b A fejtetőt helyenkint rövid apró szőrök fedik 6

6a Szőrözete barna, az orra alatti szőrcsomó vaskos, telt, felálló. A dunántúli dombos vidéken fordul elő szórványosan ${ }^{8}$, a fővárosban senki sem találta Gáyer Gyula9

\footnotetext{
1 Szakáll nélküliek (latin).

2 Szakállasok (latin).

${ }^{3}$ Szepesfalvy (Szurák) János (1882-1959) a Nemzeti Múzeum Növénytani Osztályának mohásza, 1925től Szepesfalvyra magyarosított.

${ }^{4}$ Jellegzetesen felfelé álló bajusz. Utalás II. Vilmos német császár bajuszára, és a császár borbélya,

Francois Haby bajuszkenőcsére, melynek „es ist erreicht” volt a neve.

${ }^{5}$ Harminc éves korában, 1901-ben feleségül vette Fellner Etelkát, akivel boldog, harmonikus családi életet élt (BoGSCH 1937).

${ }^{6}$ Kubacska András (1871-1942) a budapesti Fasori Evangélikus Gimnázium természetrajz-földrajz tanára.

${ }^{7}$ Gombocz Endre (1882-1945) a Veres Pálné Leánygimnázium tanára, 1903-tól jelentek meg cikkei botanikatörténeti témában (JáVORKA 1947).

8 1906-tól ügyvédjelölt Celldömölkön, 1909-től a komáromi törvényszéken joggyakornok, majd 1911-

től a vasvári királyi járásbíróság jegyzője.

${ }^{9}$ Gáyer Gyula (1873-1947) a vasvári királyi járásbíróság jegyzője (BALOGH 2002).
} 


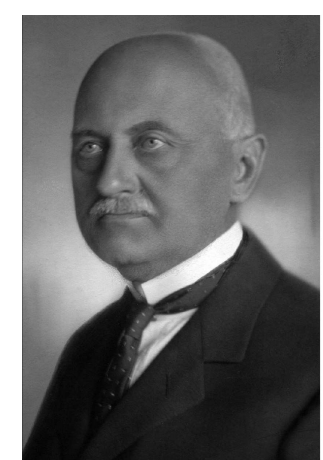

Deér Endre

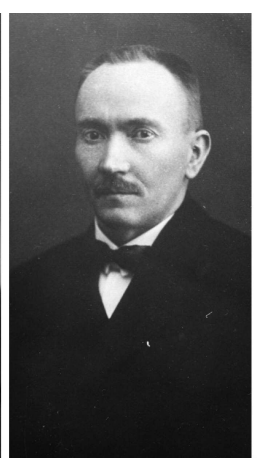

Andrasovszky József

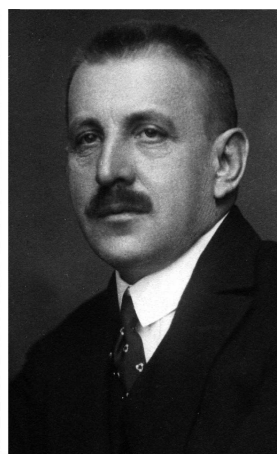

Szabó Zoltán

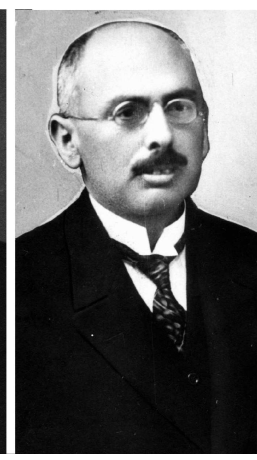

Polgár Sándor

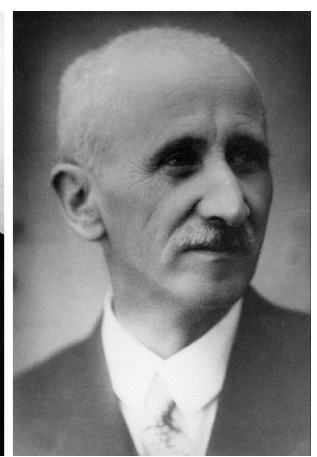

Kümmerle J. Béla

6b Szőrözete szürkésfehér, az orra alatti szőrcsomó rövid, nyírott, haja majdnem egészen fehér, a miért egyszer elnökölt a szakosztályban ${ }^{10}$. Télen a Ferenc ${ }^{11}$ és Józsefvárosban ${ }^{12}$ nyáron a Balaton ${ }^{13}$ mellett van elterjedve

Deér Endre ${ }^{14}$

7a A fej szőrözete rövidebb, felálló 8

7b A fej szőrözete hosszabb, odasimuló 19

8a A fejszőrözete téglavörös, az orra alatt kissé vörösesen pelyhesedő, egyszer előfordult Kisázsiában ${ }^{15}$ is Andrasovszky József ${ }^{16}$

8b A fejszőrözete másszínú 9

9a Bajusza nyírott, füle elálló

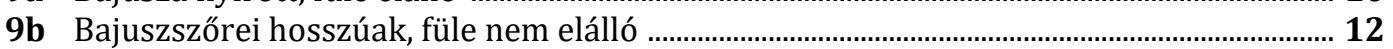

10a Képe ráncos, orra egyenes savanyúképű, háta görbe. Rájött, hogy a Knautiáknak hét bőre van és ezt mind külön lehet lehúzni és kiadatni ${ }^{17}$ Szabó Zoltán 18

10b Képe nem vagy alig ráncos, orra görbe 11

11a Nyaka rövid gallérjánál rövidebb, feje gömbölyű, orrán üvegezett csiptetőt hord, fogai messziről is jól láthatóak, fehérek

Polgár Sándor ${ }^{19}$

11b Nyaka megnyúlt, gallérjából kiemelkedő, feje hosszúkás, csiptetőt hord, beszéd közben majdhogy le nem nyeli a fejét, hozzászól a tárgyhoz akár kell, akár nem

12a Es ist erreicht ${ }^{21}$

Kümmerle Jenő Béla ${ }^{20}$

12b Es ist nicht erreicht

\footnotetext{
${ }^{10}$ A Növénytani Szakosztály 1910. február 9-én tartott 153. ülésén Klein Gyula a tisztújítás ideje alatt átadta az elnöki pozíciót a korelnöknek, Deér Endrének (ANONYMus 1910a).

11 Híres patikája a „Jó Pásztorhoz” Bp. Ráday utca 11-13. szám alatt a Ferencvárosban volt a Budapesti Czim- és Lakjegyzék alapján.

12 Lakása Bp. VIII. ker. Józsefvárosban, az Üllői út 16/a-ban, majd 1913-tól már Bp. IX. ker. Ráday utca 26-ban volt a Budapesti Czim- és Lakjegyzék alapján.

13 Deér Endre és családja a nyarat általában a Balatonnál töltötte, Balatonfüreden a Széchenyi sétánynál volt telke, melyre házat akart építeni (HoNTi 2014).

14 Deér Endre (1865-1938) gyógyszerész.

15 Egyetemista korában 1911-ben járt Kis-Ázsiában (ANDRASOvSZKY 1914).

16 Andrasovszky József (1889-1943) az Ampelológiai Intézet munkatársa.

${ }^{17}$ A Dipsacacae család és a Knautia nemzetség specialistája megírta a Knautia nemzetség monográfiáját (SzABó 1911), azt megelőzően 8 cikkben számolt be a nemzetség vizsgálatával kapcsolatos eredményeiről.

${ }^{18}$ Szabó Zoltán (1882-1944) az Állatorvosi Főiskola és a Budapesti Egyetem magántanára.

19 Polgár Sándor (1876-1944) a Győri Állami Főreáliskola tanára.

${ }^{20}$ Kümmerle Jenő Béla (1876-1931) a Nemzeti Múzeum Növénytani Osztályának munkatársa.

21 lásd: 4b
} 


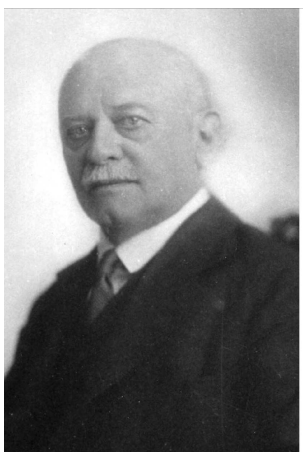

Schilberszky Károly

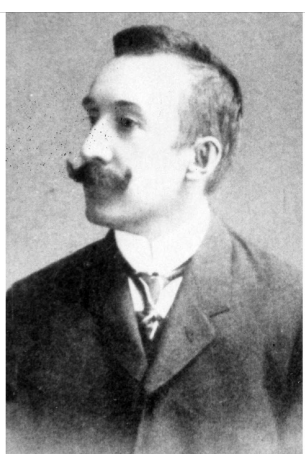

Páter Béla

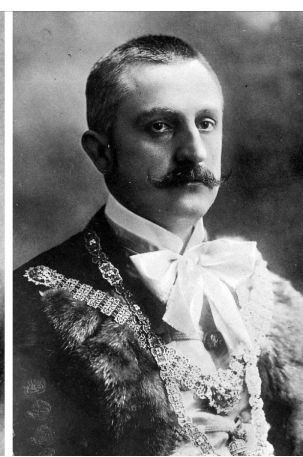

Richter Aladár

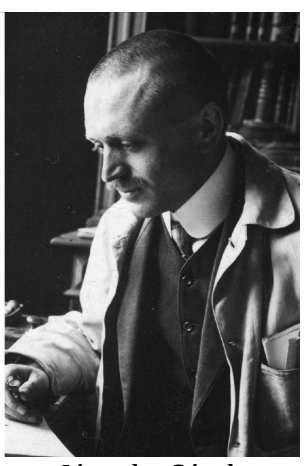

Jávorka Sándor

13a Feje kerekded, oldalszakálla majdnem a füle tövéig ér, rövid, serteszerű; mindenben a görbét, összenőttet, duplát keresi és erről előad ${ }^{22}$. Elterjedése a Gellérthegy déli lejtője ${ }^{23}$ és a tétényi plátó ${ }^{24}$, de inkább az utóbbi Schilberszky Károly ${ }^{25}$

13b Feje hosszúkás, oldalszakállát a halántékáról lelógó szőrcsomó helyettesíti. Felfedezte a növények gyógyerejét és erről ír, ír, ír. Rájött, hogy a gyógynövények kertben magról nevelhetők ${ }^{26}$. Elterjedése Erdély középső része, különösen Kolozsvár és Monostor

Páter Béla ${ }^{27}$

14a Bajusza vasárnap és fényképezéskor zsíros anyagtól összeálló, hegyes, pödrött. Miközben bejárta a világot felfedezte az európai múzeumokat ${ }^{28}$ és a világ közepét Kolozsvár$\mathrm{ra}^{29}$ helyezte át. Ố indította meg a természeti ritkaságok megóvását hazánkban, mikoris azokat szekérszámra megmenti ${ }^{30}$

Richter Aladár ${ }^{31}$

14b Bajusza sohasincsen kipödörve 15

15a Fejszőrei szőkék

15b Fejszőrei barnák 18

$16 a \mathrm{Az}$ orra alatt összevisszakuszált hosszabb serték lógnak vagy merednek, álla rendesen sertéktől érdes, képe rendezetlen. Ritkán beszél, de ekkor is ember legyen a ki megérti. Előadáskor rendesen háttal áll a közönség felé és úgy mormogja el az üres táblán mutogatva mondókáját ${ }^{32}$

\footnotetext{
${ }^{22}$ A teratológia volt az egyik fő kutatási témája, 1904-től a növényteratológia és -patológia magántanára volt a Budapesti Egyetemen.

23 1894-től a Kertészeti Tanintézet növénytanszékének tanára, mely már akkor a Gellért-hegy déli oldalán működött.

24 Tétényi otthonában érezte jól magát nyáron, ahol gyümölcsfái és kedves növényei fejlődésében gyönyörködhetett (Husz 1938).

25 Schilberszky Károly (1863-1935) a Budapesti Kertészeti Tanintézet növénytan-tanára.

26 1904-ben Kolozsváron megszervezte a világ legelső gyógynövény-kísérleti állomását, melyet 1931-ig igazgatott (FARKAS \& LÁZÁR 2010).

27 Páter Béla (1860-1938) 1893-tól a kolozsmonostori gazdasági iskolában tanított, 1910-től az iskola igazgatója, 1907-től a Kolozsvári Egyetem magántanára.

${ }^{28}$ Richter Aladár számos külföldi botanikai intézményt meglátogatott, tapasztalatait kétkötetes könyvében írta meg (RichTER 1904, 1905).

${ }^{29}$ Richter 1899-től 1913-ig a Kolozsvári Növénytanszék vezetője volt, külföldi tapasztalatai alapján nagy tervekkel vágott neki a tanszéki növénygyűjtemény fejlesztésének (NYÁRÁDY 1941).

${ }^{30}$ A Kolozsvári Egyetem herbáriuma számára, tanítványaival együtt jelentős herbáriumi anyagot gyűjtött (NYÁRÁDY 1941).

31 Richter Aladár (1868-1927) a Kolozsvári Egyetem Növénytanszékének tanára.

32 JávorKa (1941) maga is elismerte, hogy nem a legjobb előadó.

33 Jávorka Sándor (1883-1961) a Nemzeti Múzeum Növénytani Osztályának munkatársa.
} 


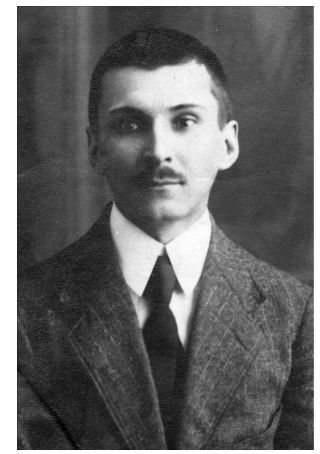

Lendl Adolf

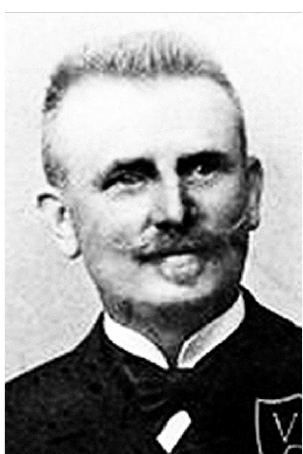

Pályi Sándor

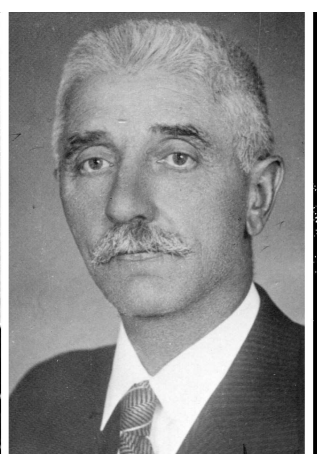

Tuzson János

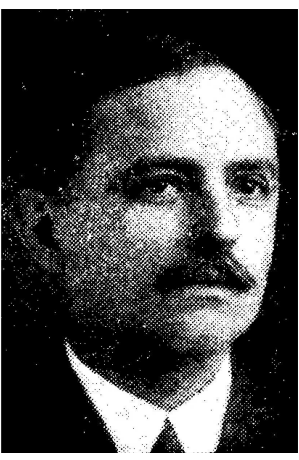

Bezdek József

17a Termete alacsony, arca beesett. A kezeibe került állatokat vagy kitömi kóccal ${ }^{34}$ vagy szabadjára ereszti az u.n. állatkertben, ahol azt az újítást hozta be, hogy az emberek ülnek a Gundl ${ }^{35}$ nevű ketrecben és a vadállatok kószálnak szabadon Lendl Adolf ${ }^{36}$

17b Termete magas, arca telt. Folyton szabadoktat és előad ${ }^{37}$. Az iskolában azt az újítást hozta be, hogy a gyerekek nem felelnek és ő se magyaráz Pályi Sándor ${ }^{38}$

18a Oldalszakálla nincs, nyaka gallérjából hosszan kiálló, bajusza tömör. Japánban sose volt, a magyar pusztát az orosz steppéken tanulmányozza39, amit ázsiai axpedíciónak nevez. Mindent feljegyez és mindent elfelejt, az asztalt telerakja papirossal, amelyek 2568 előmunkálatot és megbízást rejtenek magukban. Jelenleg minden idejét egyetlen nagy munkája a rendszeres növénytan ${ }^{40}$ kézikönyve, az Arabisek, Fritillariak, stb. stb. fejlődéstörténeti monographiája ${ }^{41}$, a magyar flóra növényföldrajza, a nagy Alföld kutatása ${ }^{42}$, a magyar dendrológia, a magyar fosszilis növények leírása ${ }^{43}$, az orosz steppék növényzete stb. stb. foglalja le, közben tanár itt, tanár ott ${ }^{44}$ és felettünk csattogtatja szerkesztői ollóját ${ }^{45}$.. Tuzson János ${ }^{46}$

18b Oldalszakálla van, nyakát magas gallér borítja, bajusza kisebb, már Japánban is volt, megerősítette az előző kutató véleményét pedagógiai szempontból ${ }^{47}$, amely szerint oda is lehet menni és vissza is lehet jönni Bezdek József 48

\footnotetext{
34 1890-től 1894-ig múzeumi segédőr volt a Nemzeti Múzeum állattárában, majd nyilvános állattani laboratóriumot és tanszerkészítő intézetet alapított. Utazásain a Magyar Nemzeti Múzeum számára is sok anyagot gyüjtött.

${ }^{35} \mathrm{Az}$ állatkert mellett mai napig működő étterem 1910-ben került a Gundel család birtokába.

36 Lendl Adolf (1862-1943) részt vett a Budapesti Állat- és Növénykert újjászervezésében. 1911-ben az intézmény igazgatója lett. Ô volt a modern budapesti állatkert megalkotója (ANGHI 1964).

37 1893-ban alapítója a Szabad Líceumnak, melynek célja, hogy sorozatos előadásokat szervezzen, hogy az érdeklődők tudományos és múvészeti ismereteiket gyarapíthassák és fejleszthessék (BEKE 1929). 38 Pályi (Pavlicsek) Sándor (1859-1929) budapesti főgimnáziumi tanár.

${ }^{39}$ Az Alföld növényföldrajzi kutatásával kapcsolatban 1912-ben a dél-oroszországi sztyepp régióba látogatott (Tuzson 1913).

40 Növénytan-tankönyvet is írt (Tuzson 1911, 1926).

41 Több rendszertani dolgozata is megjelent a Potentilla, Daphne, Arabis, Fritillaria nemzetségekelről.

42 A Magyar Földrajzi Társaság támogatásával és Kiss József tanársegéd segítségével a Nyírség növényzetét vizsgálta (ANONYMUS 1940).

43 Számos publikációja jelent meg a fosszilis flóráról.

44 1905-től a műegyetemi állásával párhuzamosan a Budapesti Egyetem növényhisztológia magántanára, majd 1909-től a növényrendszertan megbízott előadója volt.

45 Szerkesztette a Botanikai Közleményeket, és előzményét, a Növénytani Közleményeket (1902-1908).

46 Tuzson János (1870-1943) a Mủegyetem növénytanszékének adjunktusa.

47 1911-ben járt Japánban, ahol növényeket is gyüjtött, az ország oktatási rendszeréről cikkeiben

(BEZDEK 1912) és könyvében (BEZDEK 1913) számolt be.

48 Bezdek József (?-?) a X. kerületi Kőbányai Állami Gimnázium földrajz-természetrajz tanára.
} 


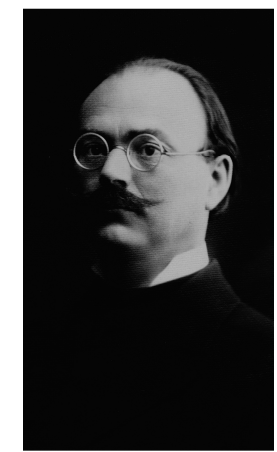

Győrffy István

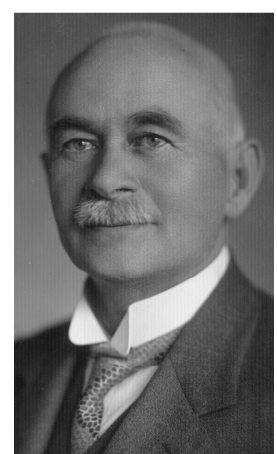

Wagner János

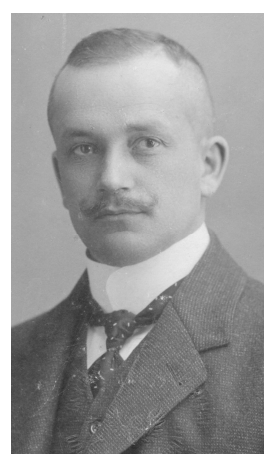

Szalóky Róbert

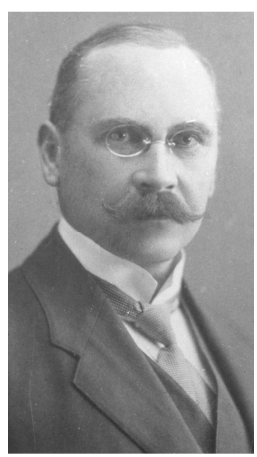

Moesz Gusztáv

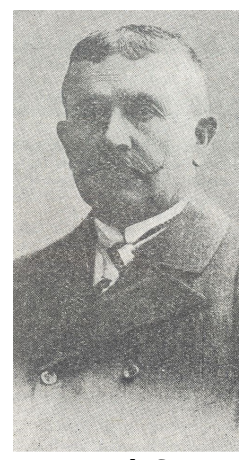

Kupcsok Samu

19a A fej szőrzete sörényes, szálai hátul a gallérig lógnak. Üvegen keresztül nézi a világot, a mely mohákból áll. Szekérszám közli az új termőhelyeket a nagy emberek halála és születése napján. A világ legalázatosabbja

Győrffy István ${ }^{9}$

19b A fej szőrözete rövidebb 20

20a A fej tetején a szőrözet gyéresedik, már nem soká tart ........................................................ 21

20b A fej még tömör, vaskos szőrözettel fedett ............................................................................. 23

21a Szőrei deresek, fehérek, bár arca piros, üde. Kisütötte, hogy hazánkban több Centaurea faj van mint az egész világon és ezek is összeporzódtak, hogy más se ismeri ki őket mint

21b Szőrei még nem deresek a tudomány mai állása szerint

Wagner János ${ }^{50}$

22a Bajusza kicsiny, sötétszínű, feje nyúlt, szögletes, szeme üvegtelen, kifejezése ünnepélyes; o fedezte fel hogy a róth magyarul

Szalóky Róbert ${ }^{51}$

22b Bajusza nagyobb, világosabb, feje kerek, arca piros, szeme üvegezett, kifejezése joviális; Szakosztályi ügyek címen folytatólagos előadást tart, vezeti a jegyzőkönyvet ${ }^{52}$. Vacsorákra a hóna alatt nagy zöld könyvet cipel tekintélye kedviért. Éjszakánkint összeálmodott dolgokat lepingál és mint gombákat ad be a szakosztálynak

Moesz Gusztáv 53

23a Szőrözete világos, szőke 24

23b Szőrözete sötétebb vagy barna 27

24a A fejtető szőrözete középen választékkal, a szőrözet innen jobbra és balra hajlik. Felfedezte, hogy egy-egy szederbokron 100-200 faj is megkülönböztethető, sőt a levél alsó és felső fele, színe és fonáka más-más fajhoz tartozik

Kupcsok Samu ${ }^{54}$

24b A fejtető szőrözete oldalsó választékkal 25

25a A fejtető szőrözetének választéka jobboldalon van. Hajzat rendezett, szabályos. A főváros tápszerhamisító üzemének szakértő előmozdítója ${ }^{55}$, ugyanott mint zuzmászt ${ }^{56}$ vegyészként alkalmazták a paprika mikroszkópi elemzésére ${ }^{57}$ Tomek János

25b A fejtető szőrözetének választéka baloldalon van 26

\footnotetext{
${ }^{49}$ Győrffy István (1880-1959) középiskolai tanár Lőcsén. Ebben az időszakban elsősorban a Tátrából és Erdélyből közölt új mohaadatokat.

50 Wagner János (1870-1955) a VI. kerületi Felsőerdősori Nőképző Intézet igazgatója. A Centaurea nemzetség hazai monográfusa, számos fajt és hibrid eredetű alakot írt le (KÁRPÁTI 1962).

51 Szalóki (Roth) Róbert (1873-1927) a budai főgimnázium tanára, Rothról magyarosította a nevét.

52 A Növénytani Szakosztály jegyzője volt (1908-13).

53 Moesz Gusztáv (1873-1946) a Magyar Nemzeti Múzeum Növénytani Osztályának gombásza.

${ }^{54}$ Kupcsok Samu (1850-1914) bakabányai tanító, több mint 180 Rubus taxont írt le.

55 Tomek János (1879-1956) 1907-től a Vegyészeti és Élelmiszervizsgáló Intézetben helyezkedett el, melynek egyik fő feladata volt, hogy kiszűrje a hamisított tápszereket a forgalomból.

56 Kezdetben zuzmókkal foglakozott (ANONYMUS 1910b).

57 cf. Томек (1919)
} 


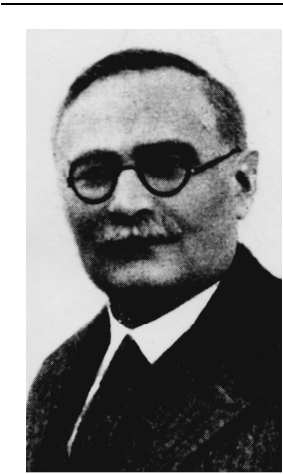

Hollendonner Ferenc

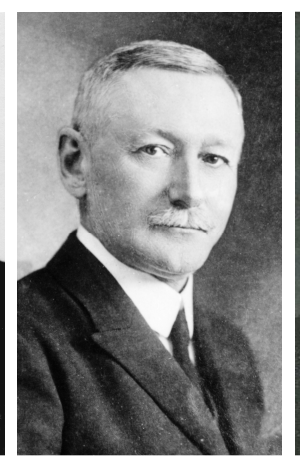

Thaisz Lajos

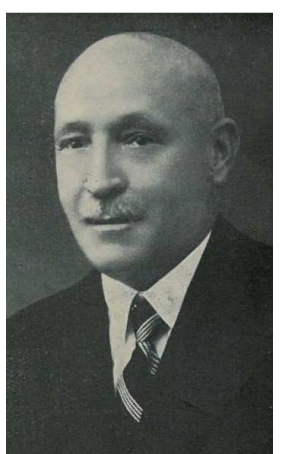

Haerter Ádám

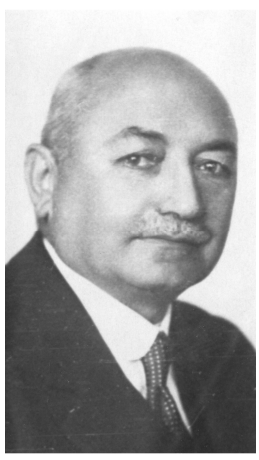

Kövessy Ferenc

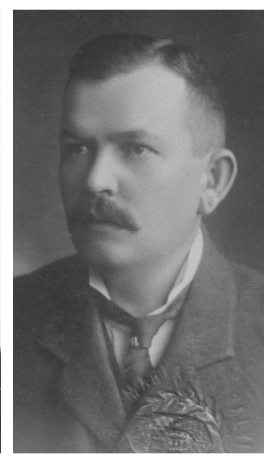

Péterfi Márton

26a Bajusza hatalmas, tápfelvevő üregét is befedi, arca kerek, állkapcsai gallérjánál szélesebbek, mindig szemüveggel jár. Bebizonyította, amit régen tudunk, hogy a Biota nem Thuja és az orientalis nem occidentalis ${ }^{58}$. Olyan képet vág mintha semmit se tudna Hollendonner Ferenc ${ }^{59}$

26b Bajusza rövidebb, tápfelvevő üregét nem fedi be, arca nyúlt, állkapcsa gallérjánál nem vagy alig szélesebb, néha cvikkert használ és ezzel vadászik lóháton a locus classicusokra ${ }^{60}$. Gazdag tapasztalatai révén ministernek referál a jó és a rossz legelőkről, mert ő fedezte fel, hogy a növényevő állatok füvet esznek tekintettel a pontos határozásra és prioritásra. Olyan képet vág, mintha mindent tudna

Thaisz Lajos 61

27a A fej szőrözetén nincs határozott választék, a homlok kétoldalt a fejtető közepéig ér ..... 28

27b A fej szőrzetén választék van

29

28a Bajusza hosszú, pödrött, sohasem hall róla az ember

Haerter Ádám 62

28b Bajusza nyírott, mindig hall róla az ember. A felső mathesis segélyével konstatálta, hogy a fák minél öregebbek, annál nagyobbak és vastagabbak

Kövessy Ferenc ${ }^{63}$

29a Bajusza hosszabb, szőrei kétoldal felé nézők 30

29b Bajusza nyírt, szőrei előre vagy lefelé nézők 32

30a Bajusza kétoldalfelé lapul. Elterjedése hazánk keleti része, ahol az északi Győrffyt helyettesíti a mohászatban Péterffi Márton64

30b Bajusza pödrött 31

\footnotetext{
58 cf. HOLLENDONNER (1912)

${ }^{59}$ Hollendonner Ferenc (1882-1935) a Múegyetem Növénytanszékének tanársegéde.

60 Hivatali munkája mellett aktívan kapcsolódott be a magyar flórakutatásba is.

61 Thaisz Lajos (1867-1937) 1910-től a Földművelésügyi Minisztériumban volt a rét- és legelőgazdálkodási ügyek vezetője.

62 Haerter Ádám (1886-1946) a Budapesti Egyetem befejezése után, egy rövid ideig a Műegyetemen dolgozott, majd 1904-től (?) a zalaegerszegi állami főgimnáziumban, ezután 1911-től a ceglédi gimnáziumban tanított (DoMÁN 1986, SzŐNYI 1940).

63 Kövessi Ferenc (1875-1945) a Bányászati és Erdészeti Főiskola Növénytani Tanszékének tanára. Számos cikke jelent meg a fák növekedéséről, melyekben matematikai törvényszerüségek alapján próbálta leírni a jelenséget (BARTHA 2009).

64 Péterfi Márton (1875-1922) segédőr az Erdélyi Múzeum növénytani osztályán, mely ekkor a Kolozsvári Egyetem keretein belül működött. Elsősorban mint mohász volt ismert (GYőRFFY 1924).
} 


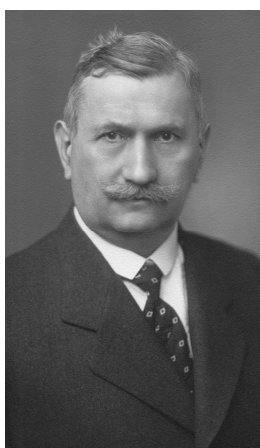

Augusztin Béla

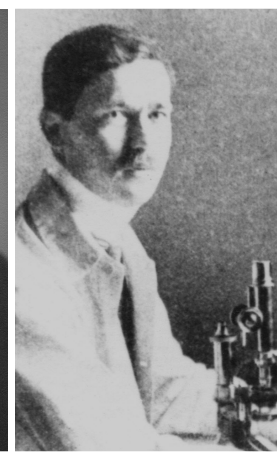

Fucskó Mihály

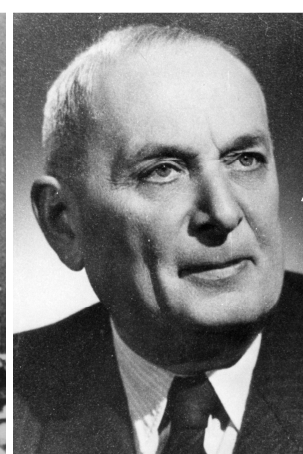

Lengyel Géza

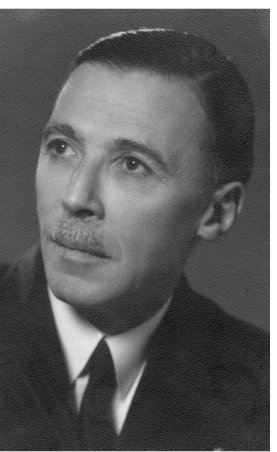

Weber Dezső

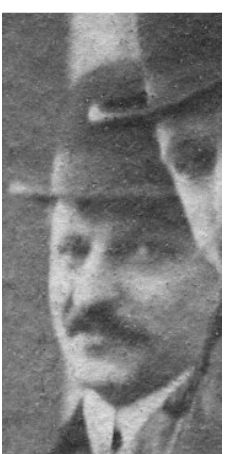

Timkó György

31a Pocakos, oldalszakálla van, képe kerek. Beszéd közben balkezét a balfüle mögé tartja, jobbkezével a mellényit vakarja. A gyógyszerészek között botanikai szakértő ${ }^{65}$, a botanikusok között pedig chémikus ${ }^{66}$. Igen gazdag citátumai alapján feldolgozta a paprikát ${ }^{67}$ a mely szóra arca kerekképűvé válik

Augusztin Béla

31b Nem pocakos, oldalszakálla nincs, képe nyúlt, különösen előadásai után, a melyekben a növények alakbeli tulajdonságainak alkalmazkodását a megfigyelő elmebeli állapotához meggyőző bizonyítékokkal derítette fel

Fehér Jenő 68

32a Orra krumpliszerű, miértis állandóan a krumplival foglalkozik, amelyről azt a felfedezést tette, hogy a legnagyobb pipafüstben is kisarjadzik ha akar, és arra görbül a szára amerre akar, nedvesen elrothad, szárazon kiszárad

Fucskó Mihály ${ }^{69}$

32b Orra éles metszésű 33

33a Tokája nincs 34

33b Tokája van, arca piros pozsgás, gömbölyű, minden növényt hasból megismer, ha ő beszél, más szóhoz nem jut, és még hozzá mindig az ember lábára lép és mindent kétszer mond kétszer mond 70

Lengyel Géza71

34a Homloka alacsony, arca piros, szűzies miért is szakosztályi szűzbeszédénél tovább még nem vitte ${ }^{72}$

Weber Dezső 73

34b Homloka magas, arca halvány

35a A fej sörénye hátrafésült, vaskos. Rájött, hogy az ethnográfia nem művelhető az iparcsarnokban ${ }^{74}$, miért annak zuzmológiai ágához fogott Timkó György ${ }^{75}$

35b A fej sörénye oldalra fésült 36

${ }^{65}$ Agusztin Béla (1877-1954) a Budapesti Egyetemen végzett gyógyszerész szakon 1899-ben, 10 évig ugyanitt tanársegédként a gyógyszerészhallgatóknak oktatott növénytant (SzABó 2015).

66 Számos cikke jelent meg, melyben növények kémiai összetételével foglalkozott.

${ }^{67}$ Disszertációját a paprikatermés szövettana témakörében írta, ezen kívül is számos cikke jelent meg a paprikáról.

68 Fehér Jenő (?-?) gimnáziumi tanárnak számos cikke jelent meg virágzásbiológiával kapcsolatban, s behatóan foglalkozott a rendellenes virágokkal.

${ }^{69}$ Fucskó Mihály (1885-1914) a selmecbányai evangélikus líceum tanára. A burgonya hipertrófiás szövetei címen jelent meg dolgozata (FucsKó 1912).

70 Karinthy Frigyes Így írtok ti című könyve 1912 év elején jelent meg. Az ebben olvasható Ady-paródiára utal (Hady Endre: A Törpe-fejűek): „Hát maga megbolondult, / Hogy mindent kétszer mond, kétszer mond?” ${ }^{71}$ Lengyel Géza (1884-1965) a budapesti Vetőmagvizsgáló Állomás munkatársa.

72 1908. március 11-én tartotta első és egyben utolsó előadását a Növénytani Szakosztályban

(ANONYMus 1908), termés- és maganatómiai közleménye jelent meg (WEBER 1908).

73 Wéber Dezső (1883-1952) gyógyszerész Deér Endre Ráday utcai patikájában (ZBoRAY 1985).

${ }^{74}$ Az egyetem után 1902-től a Magyar Nemzeti Múzeum Néprajzi Osztályán dolgozott, amely 1906-tól

1924-ig a városligeti Iparcsarnokban volt elhelyezve.

75 Timkó György (1881-1945) zuzmász a Nemzeti Múzeum Növénytani Osztályán. 


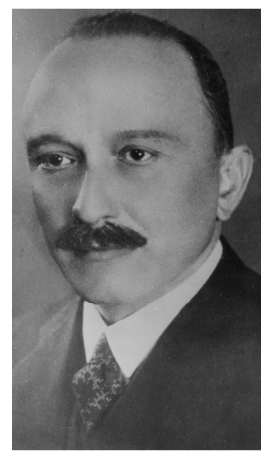

Paál Árpád

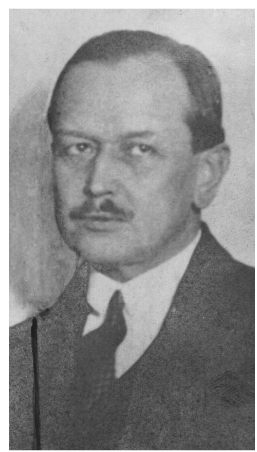

Doby Géza

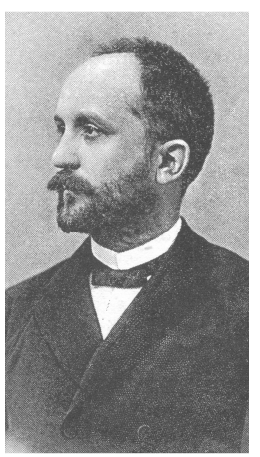

Mágócsy-Dietz

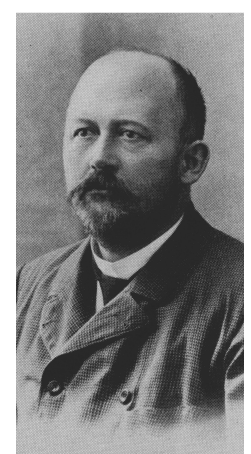

Hollós László

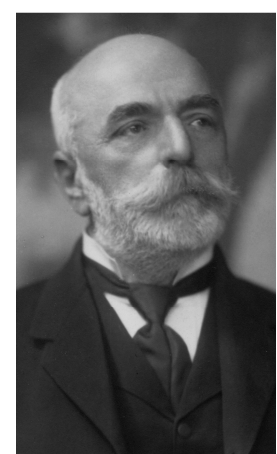

Filarszky Nándor

36a Orra alatt barnásan pelyhesedő szőrözet verődik, orra egyenes. Kísérleteiben a zónaidőn kívül a prezentációs időt alkalmazta, a mely szerint a gyökerek izgalmi állapotait tanulmányozva rájött, hogy a nem egyenes gyökerek görbék ${ }^{76}$

Paál Árpád77

36b Orra alatt fejlettebb szőrözettel, orra arisztokratikus hajlású. Mindig kukoricáz ${ }^{78}$ és enzimáz ${ }^{79}$, amit minden gazba bele magyaráz

Doby Géza ${ }^{80}$

37a A fejtető kopasz, fényes vagy alig szőrösödő 38

37b A fejtető tartósan szőrös

41

38a A fejtető teljesen kopasz, különösen este fénylik 39

38b A fejtető rövid, puha, felálló ritkás szőrözet fedi, a mely oldalt és hátul sűrűbb szőrözetbe megy át. Úgy a fejbőr, mint az arc színe minden új faj hallatára haragos vörössé változik, de minden fajbevonás hallatára ismét felderül 81 Mágócsy-Dietz Sándor ${ }^{82}$

39a Szemén üvegezett karikát visel, igen barátságos arcú Gesell János ${ }^{83}$

39b Szemén nem visel üvegezett karikát, arca nem, vagy ritkán barátságos 40

40a Feje kerek, állkapcsának szőrözete barna, hegyesedő, orrhegye fehér. A gombológia atyarajzmestere $^{84}$ Hollós László ${ }^{85}$

40b Feje hosszúkás, állkapcsának szőrzete szürke, lekerekített, orrhegy vörösödő. Behozta a természetes leltározási műrendszert ${ }^{86}$ a kombinált arabs-római-görög-perzsa és szanszkrit szám és betújegy csoportosítások segélyével a morfológiába ${ }^{87}$. Az üléseken nem ad elő ${ }^{88}$ és nem szól hozzá, az utóbbi helyett véleményét csak feje rázásából és az így véletlenül kirázott hangokból kell kitalálni, amely sohasem kedvező az előadóra

Filarszky Nándor ${ }^{89}$

${ }^{76}$ A légritkítás hatása a geotropikus ingerfolyamatra című cikkében szereplő kutatásokra utal (PAÁL 1911).

77 Paál Árpád (1889-1943) demonstrátor a Budapesti Egyetem Növénytani Intézetében.

78 Doby fogalakozott a kukorica gyakorlati felhasználásával és a benne található oxidázzal (DoBY 1910, 1912).

${ }^{79}$ Az 1910-es évek elején számos cikke jelent meg az oxidáz enzimmel kapcsolatban (DoBy 1911, 1912).

80 Doby Géza (1877-1968) Növényélet- és kórtani állomás (Magyaróvár) fővegyésze.

81 Mágócsy néhányszor a Növénytani Szakosztályban is felszólalt azzal kapcsolatban, hogy fajokat csak megalapozott indokkal írjanak le, illetve használjanak (Anonymus 1907, 1911).

82 Mágócsy-Dietz Sándor (1855-1945) a Budapesti Egyetem Növénytani Intézetének egyetemi tanára.

${ }^{83}$ Gesell János nyugalmazott MÁV főfelügyelő anyagilag rendszeresen támogatta a szakosztály működését.

${ }^{84}$ A pöfetegekről és a földalatti gombákról készült Európa-hírű monográfiáit maga illusztrálta (MOESz 1941).

85 Hollós (Schwartzkopf) László (1859-1940) a kecskeméti gimnázium tanára, 1904-től a Magyar

Tudományos Akadémia tagja.

${ }^{86}$ Nemzeti Múzeum Növénytani Osztályának vezetőjeként egyik első feladatának tekintette az új leltár és a könyvtár új cédulakatalógusának elkészíttetését (MoEsz 1943).

87 FILARSZKY (1911) Növénymorphologia címú nagy terjedelmű könyvének a fejezeteit és alfejezeteit arab és római számokkal, illetve kis és nagy betűk felhasználásával tagolta.

${ }^{88} \mathrm{Az}$ első 200 ülésen 20 előadást tartott, míg az 1910-es években nem tartott egyet sem (LENGYEL 1927).

89 Filarszky Nándor (1858-1941) a Nemzeti Múzeum Növénytani Osztályának vezetője. 


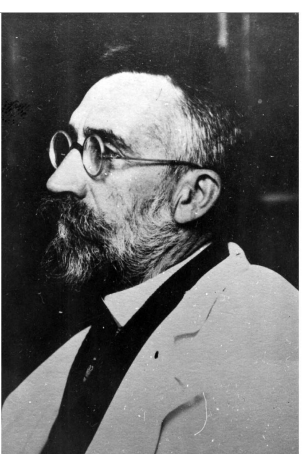

ifj. Entz Géza

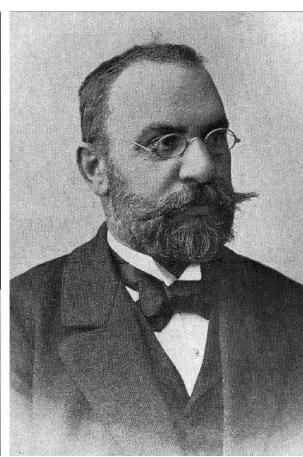

Pantocsek József

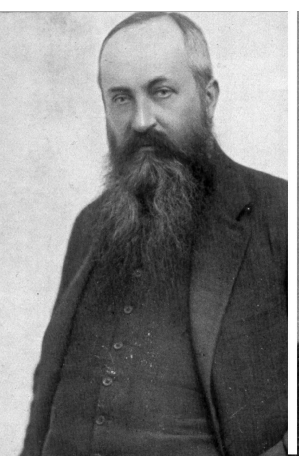

Ambrózy István

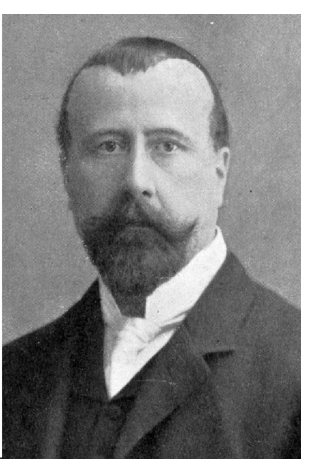

Istvánffi Gyula

41a Örökké pápaszemes szeműek

41b Sohasem pápaszemesek

42a Fejtetejét lengő hosszú szőrözet fedi, bajusza és szakálla hosszú, barnás, vékony nyakán nincs tokája, kezével beszéd közben folyton keveri a levegőt. Nem látható lényekről kötetszámra ír és előad, meglesvén mikroszkópjával ezek legbizalmasabb ténykedéseit is .. ifj. Entz Géza90

42b Fejtetejét rövid, serteszerű szőrözet borítja, szakálla rövid, vastag nyakán százrétű tokája van. Ezerszámra írja le az új diatomákat, a melyeket utána senkisem tud mégegyszer megtalálni

Pantocsek József ${ }^{91}$

43a Fejtetejét ünnepélyes alkalommal és fényképezéskor díszkalap fedi, ruházata visszaütést mutat a honfoglaló magyarok díszruhájára. Eredete is visszavezethető az ősmagyarokig, akik tiszteletére hazánkat örökké zöldelő ${ }^{92}$ Kánaánná93 akarja átvarázsolni

Ambrózy István báró 94

43b Díszkalapja nincs, sem ruházata sem eredete nem olyan mint az előbbié 44

44a A fejtetejét lesimuló álszőrözet fedi, amely gondozott szabályos. A gombákon élősködő szőlővesszőket tanulmányozza ${ }^{95}$, mindegyiket külön pavilonban. A nemzet több milliós áldozatkészségéből bebizonyította, hogy a szőlőfajtákat díszes köszörült üvegben kell termelni és minden üveget külön teremben kell kiállítani Istvánffi Gyula96

44b A fejtetejét felálló állandó és rögzített szőrözet fedi 45

45a A fej szőrözete ritkás, rövid, lásd $38 b$

45b A fej szőrözete tömör, hosszabb 46

46a Szőrözete tömör barna az egész fejen és az állon, bajusza felálló, gondozott, néha azonban mesterségesen lekapartatik. Orra sasos, odafelé görbült. Hosszas és fáradságos tanulmányok révén rájött arra, hogy az Irisek $^{97}$ és a Carpinusok ${ }^{98}$ egészen más szöveti

90 Ifj. Entz Géza (1875-1943) adjunktus a Mûegyetem állattanszékén, fő kutatási területét a növényi és állati egysejtűek képezték.

${ }^{91}$ Pantocsek József (1846-1916) a pozsonyi városi közkórház igazgató főorvosa, a kovamoszatok nemzetközileg elismert kutatója volt.

92 Malonyán (Mlyňany, Szlovákia), kastélya híres parkjában elsősorban örökzöldeket telepített.

${ }^{93}$ A Bánságban voltak birtokai, amelyet akkoriban a magyar Kánaánnak is neveztek jó földjei miatt.

${ }^{4}$ Ambrózy-Migazzi István (1869-1933) sédeni báró, nagybirtokos, a magyar förendiház örökös tagja (MoEsz 1936).

95 Több cikkében foglalkozott szőlőkön élősködő gombákkal, elsősorban a peronoszpórával. 96 Istvánffi Gyula (1860-1930) a Magyar Királyi Központi Szőlészeti Kísérleti Állomás és Ampelológiai Intézet vezetője, mely intézetet tervei alapján hoztak létre. A Törökvész dűlőben (ma Herman Ottó út) megépült új épületegyüttesnek 5 épületében összesen 322 helyiség volt, melyet pénz hiányában nem tudtak teljesen kihasználni (DEGEN 1932).

97 1909-ben Adatok a hazai Iris-fajok rhizomáinak anatómiájához címen tartott előadást a Növénytani Szakosztály ülésén (ANonYmus 1909). 


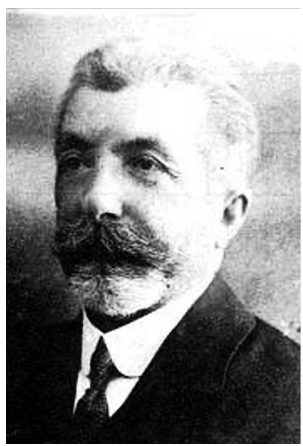

Angyal Dezső

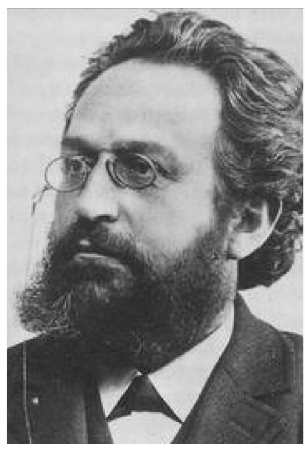

Julius Römer

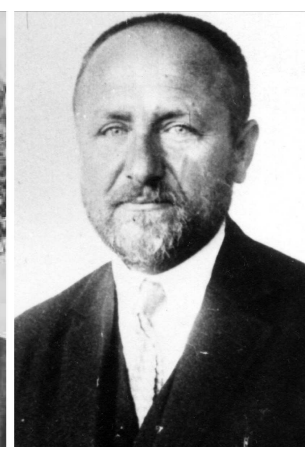

Nyárády E. Gyula

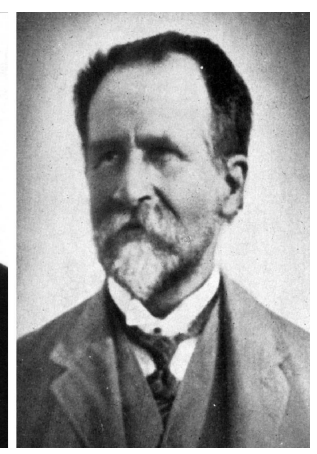

Scherffel Aladár

szerkezetűek. A vicceket szekérszámra hordja magával, a melyből nagy exportot szállított az orosz steppékre is, ahol a 18a-val együtt fordult elő99 Sztankovics Rezső ${ }^{100}$

46b Bajusza nem áll fel, szakálla ritkás vagy sűrűbb, de akkor nem barna

47a A fej szőrözete fehér, pannóniai és erdélyi flórában honos .................................................... 48

47b A fej szőrözete nem fehér, északi hegyvidéken honos .......................................................... 49

48a A fej szőrözete sűrű, nyírott, bajusza pödrött. Ő kormányozza a gyümölcsfák virágzását és termését, a magyarországi faiskolák főigazgatója. A faiskolába is behozta a közoktatásügyi rendszert, amennyiben a fanövendékeket is beoltatja és az év végén osztályozza őket ${ }^{101}$. Előfordul a Gellérthegyen

Angyal Dezső102

48b A fej szőrözete laza, lengő, bajusza lelógó. Főképen hazánk délkeleti havasain fordul elő, német elem, amely még nem honosodott meg teljesen Julius Römer ${ }^{103}$

49a A fej szőrözete szőke, szakálla és bajusza gyér. Előfordul az északi Kárpátokban ${ }^{104}$, ahol a virágosak körében különösen a fényképezés terén közkedveltségre tett szert

Nyárády E. Gyula105

49b A fej szőrözete barnás, szakálla és bajusza hol meg van, hol nincs meg, ha megvan a bajusza, akkor lelógó, rendezetlen, a szájnyílást eltakarja, ha nincs meg, úgy neki vörösödött szőrtüszők helyettesítik. A tátrai pocsolyák szorgalmas látogatója és látogatásai révén rájött arra, hogy a tátrai flagelláták is ostorosak

Scherffel Aladár106

Függelék:

50 A szakáltalanok sorából majd kimaradt, mert későn jelent meg. A 18a és 18b közé illesztendő mint átmeneti alak. Főműködése a chémiai intézet ügykörében ugyanaz, mint 25a Vargha Oszkár ${ }^{107}$

98 A hazai Carpinus-ok szövettanával is foglalkozott (SzTANKovits 1912).

${ }^{99}$ Sztankovics, aki tudott oroszul (MoEsz 1907), elkísérte Tuzson Jánost oroszországi útjára (Tuzson 1913). 100 Sztankovics Rezső (1875 körül-1951) VII. kerületi községi polgári fiúiskola tanára (a világháború utáni kiadványokban Sztankovits formában szerepelt).

101 Ő kezdeményezte a Budaörs-kamaraerdei törzsgyümölcsös létesítését, melyben a törzsfák mellett faiskola és magiskola is volt (GYúRó 1978).

102 Angyal Dezső (1852-1936) pomológus a Budapesti Kertészeti Tanintézet igazgatója, mely a Gellérthegyen működött.

103 Julius Römer (1848-1926) erdélyi szász természettudós, a brassói leánygimnázium nyugalmazott tanára, elsősorban német nyelven publikálta botanikai eredményeit.

1041904 és 1911 között a Késmárki középiskolában tanított és a Tátrában botanizált (BARTóк 2016).

105 Nyárády Erazmus Gyula (1881-1966) középiskolai tanár Marosvásárhelyen.

106 Scherffel Aladár (1865-1939) iglói botanikus, a moszatok és moszatgombák nemzetközileg ismert kutatója, aki elsősorban a Tátrában gyüjtött (ENTZ 1941).

107 Varga Oszkár (1873-1947) a Vegyészeti és Élelmiszervizsgáló Intézet fővegyésze. 